\title{
Starch-Glycerol Based Edible Film and Effect of Rosella (Hibiscus Sabdariffa Linn) Extract and Surimi Dumbo Catfish (Clarias gariepinus) Addition on Its Mechanical Properties
}

\author{
Endaruji Sedyadi', Syafiana Khusna Aini ${ }^{2}$, Dewi Anggraini ${ }^{3}$, Dian Prihatiningtias Ekawati ${ }^{4}$ \\ ${ }^{1,2,3,4}$ Chemistry Department, Faculty of Science and Technology, UIN Sunan Kalijaga, \\ J1. Marsda Adisucipto No 1 Yogyakarta 55281, Indonesia. Tel. +62-274-540971, Fax. +62-274-519739
}

Author correspondency:

endaruji@yahoo.com ${ }^{1}$

\begin{abstract}
Effect of Rosella (Hibiscus Sabdariffa Linn) Extract and Surimi Dumbo catfish (Clarias gariepinus) addition on Starch-Based Edible Film-Glycerol Mechanical Properties has been done. The purpose of this study is to create an active environment-friendly packaging material. Surimi additions are intended to improve the mechanical properties of bioplastics and additions of Rosella extract intended as a bio-indicator of acidity. The method used was Solvent Casting. An amount of surimi and rosella extract varied to obtain the best mechanical properties. The results shows that the addition of surimi and rosella flower extract significantly effect the elongation of Edible films produced up to $27 \%$.
\end{abstract}

Keywords: Edible film; Rosella Extract; Surimi Dumbo catfish; Mechanical Properties.

\section{INTRODUCTION}

The use of synthetic polymers made from petroleum may have a negative impact on our environment and on human health. Synthetic polymers made from petroleum take a long time to degrade (Awwaly et al., 2010). The awareness to this problem would then increasing interest to organic materials, which can be destroyed biologically, eco-friendly, and easily obtained in nature as well as suitable for packed food products (Embuscado et al., 2009). The ideal solution is the development of natural ingredients for the manufacture of packaging materials which can be decomposed faster naturally, maintain the integrity of the food product to be packed and Edible (Gennadios et al., 2002).

Edible film is a thin layer made of edible ingredients and used as food coating. Coating of food components can be done by dipping, spraying or wrapping (Akbar et al., 2013). The advantage of using edible film is it can be directly consume with the products that are packaged together, eco-friendly, improve the organoleptic properties of the packaged product, serves as a nutritional supplement, as a carrier of flavor, coloring, antimicrobial agents, and antioxidants (Murdianto et al., 2005).

Hydrocolloid such as proteins, polysaccharides, and a mixture of both has been studied intensively as an ingredient in edible film. Isnaini (2010) explains that the edible film as bio-indicators can be made by using natural pigments from the plant, one of them is Rosella (Hibiscus Sabdariffa L). The main ingredients of Rosella is an anthocyanin. Setiono (2013) stated that anthocyanins are dissolved in water to create colored solutions, red under acidic conditions and blue under alkaline conditions. The compound is classified as pigments and determine the plant color which is affected by the $\mathrm{pH}$ of its environment. Rosella flowers can be used as bio-indicators, which are sensitive to $\mathrm{pH}$. Edible films can detect food spoilage by change in $\mathrm{pH}$ of the food (Akbar et al., 2013).

Edible films based on protein has been developed, such as the filming of collagen, gelatin, protein maize (corn zein), wheat protein (wheat gluten), soy protein (soy protein), casein and whey protein. Based protein film are usually obtained from casting and drying (Valenzuela et al., 2013). An alternative materials of edible film made from a protein is surimi. Park (2004), explains that the surimi is a myofibril fish protein which has been stabilized and is manufactured through a continuous process stage which involves the removal of the head and spine, meat processing, washing, removal of water and freezing. Surimi has the functional ability in gel form and bind water (Amaliya et al., 2014).

In this research, Catfish surimi protein is added to improve the mechanical properties and lowering the water vapor transmission rate so its improve the shelf life of the product that is coated. Rosella extract in this study is used as bio-indicators sensitive to $\mathrm{pH}$ changes that occur in food to be packaged (Amaliya et al., 2014). Edible film is expected to detect food spoilage by changes in $\mathrm{pH}$ that occur in food, have good mechanical properties and low WVTR. 


\section{MATERIALS AND METHODS}

\section{Materials}

Materials used in this research are rosella flower petals from Wonosobo, Dumbo catfish obtained from Candipitu Karangmojo, Gunungkidul Yogyakarta, Commercial tapioca Rosebrand, glycerol, sodium hydroxide pellets p.a Merck, silica gel obtained from Bratachem, 96\% ethanol, and distilled water.

\section{Preparation of Rosella's Extract}

The extraction method in this research was maceration (Marwati et al., 2012). A hundred grams of rosella were added to $300 \mathrm{ml} 96 \%$ of ethanol at room temperature for 24 hours. Solution then filtered and evaporate to give a sticky extract of rosella.

\section{Preparation of Dumbo Catfish's Surimi}

Surimi preparation of Dumbo catfish in this research has done using Heruwati \& Jav method (1995) methods in Santoso et al. (2013). One kilogram of catfish was weeded by removing the head and entrails then washed with water. Catfish meat are crushed and washed twice with cold water. The mixture was then stirred for 10 minutes. Stirring was stopped to precipitate the pulverized meat, while dirt and grease is dumped. The precipitate is then dried by pressing it in a hydraulic press to remove water (Bourtoom et al., 2006)

\section{Preparation of Edible Film \\ Tapioca-Surimi Edible Film}

Edible film preparation was modified from Santoso et al. (2011). The procedure of making this edible film are as follows. Edible surimi weighed as much as $1 \% ; 1.5 \%$; $2 \% ; 2.5 \%$ and $3 \%(\mathrm{w} / \mathrm{v})$ of the total distilled water used as solvent. A $100 \mathrm{ml}$ of distilled water then added with 1 $\mathrm{M} \mathrm{NaOH}$ and adjust to $\mathrm{pH} 11$. Mixture then stired and heated for 30 minutes at $50{ }^{\circ} \mathrm{C}$. The mixture reheated to $60{ }^{\circ} \mathrm{C}$ for 30 minutes. Addition of 2.5 gram tapioca and $1.5 \mathrm{~mL}$ of glycerol has done when the mixture were homogen. The suspension then heated and degassing for another 25 minutes, respectively. The suspension is then poured over the glass framed and dried at $50{ }^{\circ} \mathrm{C}$ for 12 hours.

\section{Tapioca-Surimi-Rosella Edible Film}

Edible film preparation method using in this research is similar to the previous method but added rosella's extract as much as $0 \% ; 1 \% ; 2 \%$; and $3 \%$, respectively. The mixture was heated for 25 minutes at $30{ }^{\circ} \mathrm{C}$ and degassed at $75 \mathrm{kPa}$ for 20 minutes. Mixture is then poured over the glass framed and dried at $50^{\circ} \mathrm{C}$ for 16 hours.

\section{Characterizations}

Characterization of materials was conducted on the WVTR, mechanical and functional group testing using FT-IR (Fourier-Transform Infrared Spectroscopy).

\section{Color Test}

Preliminary test conducted to identify anthocyanin is a color test as conducted by Supriyanti et al. (2013). This test were done with the addition of $\mathrm{HCl}$ and $\mathrm{NaOH}$. Hayati et al. (2012) stated that in the acid environment, an anthocyanin will remain red and under alkaline conditions anthocyanin change to bluish-green.

\section{Thin Layer Chromatography (TLC) Test}

Further testing is to determine the presence of anthocyanin compounds using TLC methods using $\mathrm{HCl}$ and BAA (Butanol: Acetic acid: water) as eluent.

\section{Water Vapor Transmission Rate (WVTR) Test}

Measurements were made using the gravimetric method based on ASTM. E. 96-99. Moisture absorbent materials (desiccant) were put in a can, then the sample were placed at the top of the can such that the sample covers cans. Wax paper used to cover part of the container with the sample so that no air enters between the boundary and the sample container (Bourtoom et al., 2006).

Cans are weighed to the nearest $1 \mathrm{mg}$, and then placed in a desiccator at a fixed room temperature. Cans are weighed every day at the same hour and determined the increasing of its weight as a consequence of desiccant material that had absorb water. The relationship between weight gain and time were graphed. WVTR value is calculated using the formula:

$$
\begin{aligned}
\text { WVTR } & =\text { slope } / \text { sample area } \times 100 \times 100 \mathrm{~m}^{2} \\
& =\mathrm{g} / \mathrm{m}^{2} / \text { days }\left(92 \% \mathrm{RH}, 38^{\circ} \mathrm{C}\right)
\end{aligned}
$$

\section{Mechanic Properties Test}

Edible Film mechanic properties (thickness, tensile strength and elongation) test has done based on ASTM.D. 882-02. Edible films are conditioned at room temperature $\left(30{ }^{\circ} \mathrm{C}\right), 68 \%$ humidity $(\mathrm{RH})$ for 24 hours prior to measurement.

Film thickness were measured using a micrometer to the nearest $0.001 \mathrm{~mm}$. Thickness measurements were taken at five different points for each film sample (top right corner, bottom right corner, middle, upper left corner and the bottom left corner). Film thickness value is an average of the results of measurements at five points in units of mm (National Standardization Agency, 2013).

A set equipment test is prepared and arranged. Samples of edible film mounted at the ends of both clamping and wedged firmly. The measurement area is set with loads corresponding to pen recorder off. Tensile strength is determined by the maximum load, while the elongation is determined and calculated at the time the film broke.

\section{Fourier Transform Infrared Spectroscopy}

Characterization of functional groups carried out by FTIR using a $\mathrm{KBr}$ pellet method. One mg of sample was mixed with $200 \mathrm{mg}$ of $\mathrm{KBr}$ powder. Samples were mixed in $\mathrm{KBr}$ pellets by pressed mixture into a thin 
transparent using 10 tons pressure (2000 psi). Pellet samples were then measured its infrared absorption at wavenumber $4000-400 \mathrm{~cm}^{-1}$.

\section{RESULTS AND DISCUSSION}

\section{Rosella Extraction}

Rosella (Hibiscus sabdariffa L.) was extracted using maceration method to retrieve the active substance in rosella's petals (Hayati et al., 2012). Extraction method is done by depositing the active compounds contained in the rosella petals using $96 \%$ of ethanol with a ratio of rosella's powder: ethanol $=1: 5$ for 24 hours. The yield obtained is about $26.16 \%$ of red extract yield. This thick red rosella extract obtained is not much different from those obtained a yield of $17.7 \%$ in the study of Suzery et al. (2010).

\section{Color Test}

One of the active compound in rosella flower petals is anthocyanin. This anthocyanin are red to the blue pigment found in many fruits and flowers (Robinson, 1991). This test is performed with the addition $\mathrm{HCl}$ and $\mathrm{NaOH}$. The results obtained are rosella flower petals extract supplemented with $\mathrm{HCl}$ will remain red, whereas one with with $\mathrm{NaOH}$ will turn green and faded to yellow. This is in accordance with Hayati et al. (2012), which states that under acidic conditions the anthocyanin color will remain red and bluish green in alkaline conditions. Besides affected by $\mathrm{pH}$, color changes in anthocyanin compounds are also affected by the concentration of pigments, their mixtures with other compounds as well as the number of methyl and hydroxyl groups. Hydroxyl groups changes the colors tend to be blue and unstable, while methoxyl group changes of color will tend to be red and stable (Warsiki, 2012).

\section{Thin Layer Chromatography (TLC) Test}

$\mathrm{HCl}$ mobile phase generating $\mathrm{Rf}$ value of 0.37 . This is consistent with the report by Hayati et al. (2012) that the value of $\mathrm{Rf}$ for anthocyanin is eluted with $\mathrm{HCl}$ low to mid. Research conducted by Suzery (2010) about the mangosteen fruit anthocyanins also generate $\mathrm{Rf}$ value of 0.58 . While the mobile phases BAA generate $\mathrm{Rf}$ value of 0.48 . Rf value for anthocyanin eluted with BAA is $0.1-0.4$, it is not much different from research conducted by Warsiki et al. (2012) which also ranges from 0.25.

Comparison of anthocyanin of rosella flower petals with Harbone (1987) is shown by Table 1.

Based on those preliminary tests, it can be concluded that the extract obtained from Rosella contains anthocyanins. These results were then confirmed by FTIR characterization to determine the functional groups contained in the extract. IR spectrum of Rosella flower extract is presented in Figure 9.
Table 1. Comparison antocyanin test.

\begin{tabular}{|c|c|c|}
\hline \multirow{2}{*}{ Test } & \multicolumn{2}{|c|}{ Result } \\
\hline & This research & Hayati, 2012 \\
\hline using $\mathrm{HCl} 2 \mathrm{M}$ & red & red \\
\hline $\begin{array}{l}\text { using } \mathrm{NaOH} 2 \\
\mathrm{M}\end{array}$ & $\begin{array}{l}\text { Turn to green then } \\
\text { fade to yellow }\end{array}$ & $\begin{array}{l}\text { Turn to green then } \\
\text { fade to yellow }\end{array}$ \\
\hline $\begin{array}{l}\text { TLC with } \mathrm{HCl} \\
1 \% \text { eluent }\end{array}$ & Rf value $=0,371$ & Low to middle $\mathrm{Rf}$ \\
\hline $\begin{array}{l}\text { TLC with } \\
\text { BAA eluent }\end{array}$ & Rf value $=0,25$ & $\begin{array}{l}\text { Middle Rf (0.10- } \\
0,40)\end{array}$ \\
\hline
\end{tabular}

\section{Surimi}

Surimi is a myofibril protein concentrate from successive leaching process to remove unwanted compounds, resulting in a semi-pure protein fraction containing high myofibrils protein. The making of Catfish's surimi is done by separating the meat from the head and the stomach contents of fish with several stages of the Rinsing, suppression, the addition of salt $(\mathrm{NaCl})$, and the addition of cryoprotectant. Rinsing is an important step because it can support the ability of gelation (ashi) and inhibit protein denaturation due to freezing (Santoso, 2007).

100 grams of fresh meat catfish yielded $64.86 \%$ solid white surimi. The surimi obtained are relatively small due to repeated washings during the washing process. According to Santoso (2004), during the washing process many materials are dissolve by water. Identification of functional groups on surimi has done using FT-IR at $4000-400 \mathrm{~cm}^{-1}$. FT-IR spectrum of the surimi is presented in Figure 10.

\section{Tapioca-Surimi Edible Film}

The principle of production edible film manufacture with variations of surimi was prepared by dissolving surimi under alkaline conditions. Surimi containing protein myofibril that insoluble in water but soluble in an alkaline. In addition myofibril protein denaturation is essential to form a wider structure for the film formation. Cause denaturation of proteins into long parallel chains that can bind with other polymers such as starch. Proteins can form edible film because of the ability of the side chain to form intermolecular crosslinking (Bourtoom et al., 2006).

\section{Mechanical Properties Test of Edible Film Thickness}

Edible film thickness against amount variation of catfish surimi is presented in Figure 1 which shows that the surimi edible film thickness ranged from 0.09 to 0.12 mm. Krochta (1994) explains that the film thickness correlated to the number of three-dimensional network that is formed so that the film is getting thicker. The concentration of dissolved material in the film-forming 
solution and casting plate size also affects the thickness of the film.

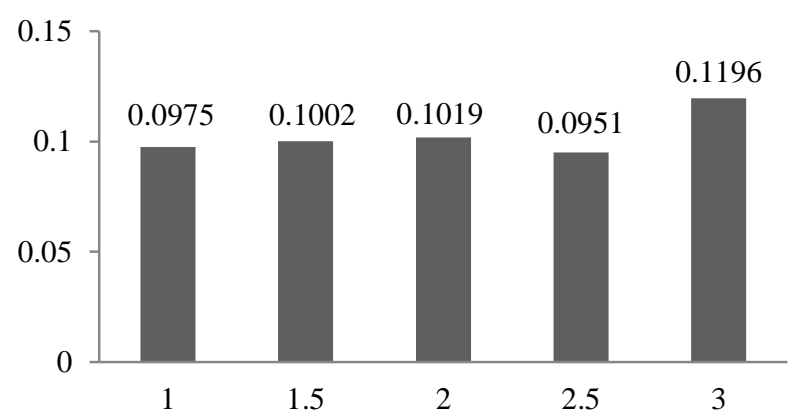

Figure 1. Graph of thickness vs surimi variation.

The results showed that the addition of surimi does not significantly affect edible film thickness.

\section{Tensile Strength}

Tensile strength is the maximum achievable pull of a film before it breaking. The tensile strength test with a variety of surimi edible film is presented in Figure 2 which shows that the tensile strength ranging between 0.83 to $1.09 \mathrm{~N}$. The best tensile strength value is $1.09 \mathrm{~N}$ with surimi concentration as much as $3 \mathrm{~g}$. Edible films with surimi addition showed a trend of increasing tensile strength values, though not very significant.

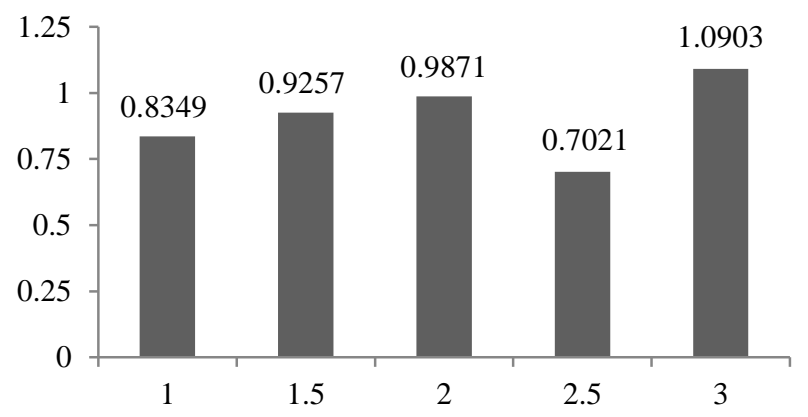

Figure 2. Graph of Tensile strength vs surimi variation.

This is consistent with Chinabhark et al. report (2007) which showed that a protein in a high amount of polymer allows the intermolecular interaction getting bigger and stronger. This causes an increase in the value of tensile strength edible film.

\section{Elongation}

Elongation is the maximum length changes of edible film during a stretch off. Flexibility properties of edible film are very important thing in the coating process food. Edible films with a elastic and flexible texture are easier to set up, so that the packing of the food is good (Cahyadi, 2009).

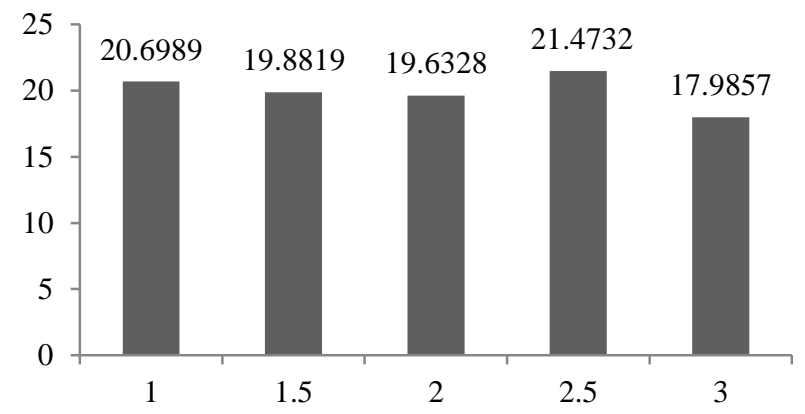

Figure 3. Graph of elongation vs surimi variation.

Elongation measurement is the maximum film length changes when obtaining tensile force to break up the film compared to the initial length (Hambali et al., 2007). The greater the elongation of edible film, edible film has more flexibility of being able to do a maximum extension. Elongation measurement of edible films in variation of surimi are presented in Figure 3.

Figure 3 shows that the edible film elongation of surimi variations tends to decrease with increasing concentration of surimi. Maximum elongation of $21.47 \%$ is achieved at a concentration of $2.5 \%$ surimi. Lowest elongation of $17.99 \%$ was obtained at a concentration of 3\% surimi. According to Sinaga et al. (2013) an edible film elongation value are low, due to the denaturation of myofibril surimi protein, and therefore contributes to a decrease in elongation.

\section{Water Vapor Transmission Rates (WVTR)}

Water vapor transmission rate is an important parameter in the edible film. Water vapor transmission rate indicates the speed of the water vapor to penetrate (per gram per second) per unit area of edible film or the film's ability to inhibit the transmission. The permeability to water vapor should be low (Garnidaet al., 2007).

The chemical composition of the food surface can be changed due to metabolism of food, microbial respiration, gas solubility, and film permeability to water vapor. Edible films rely on its barrier properties against water vapor and gas transfer. Edible film with good barrier properties can extend the shelf life of the coated products (Skurtys et al., 2009). The WVTR measurement of amount surimi variations edible films are presented in Figure 4. It appears that the WVTR values of edible film ranged from 3.59 to $4.01 \mathrm{~g} /$ $\mathrm{m}^{2}$ hours.

The results showed that the addition of surimi concentration tends to decrease the WVTR values. This is because the surimi protein undergo denaturation. Protein denaturation cause proteins undergo changes in which the hydrophilic side on the side inside and outside the hydrophobic side will turn into a hydrophobic side out so the water vapor transmission rate to be down (Santoso, 2013). 


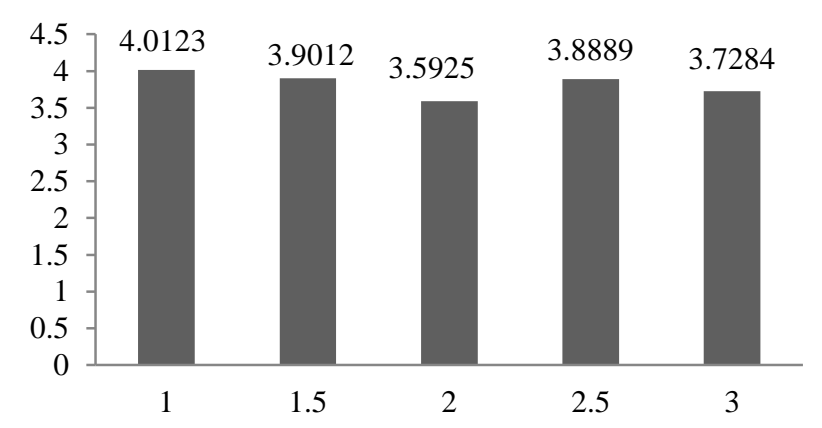

Figure 4. Graph of WVTR vs surimi variation.

Based on the mechanical test it can be concluded that the addition of surimi is not significantly affect mechanical properties of the resulting edible film. Nevertheless it can be seen that the best edible film in this study are edible film with the addition of surimi variation of $2.5 \%$ because it has the highest elongation. Edible films with this comparison will be used further to add a rosella extract.

\section{Tapioca-Surimi-Rosella Extract Edible Film}

The maximum data obtained will be used for variety addition of rosella flower extract as bio-indicators of the edible film.

The production is the same as edible film mentioned above. The suspension of the obtained printed and dried at $40{ }^{\circ} \mathrm{C}$ for 24 hours. Films were then tested the mechanical properties which include thickness, tensile strength, and elongation, WVTR and FT-IR analysis (Cahyadi, 2009).

\section{Thickness}

The results of the thickness measurements are presented in Figure 5. It appears that the edible film thickness value surimi-starch-glycerol-rosella extract produced ranged from 0.085 to $0.095 \mathrm{~mm}$. Results of edible film thickness with 2.5 grams of surimi composition and the addition of $0.75 \mathrm{~g}$ roselle extract is greater than the addition of 0.5 grams of roselle extract is equal to 0.09 $\mathrm{mm}$.

The thickness of the edible film that is formed is influenced by the film-forming solution concentration and the size of the plate. The results showed that the addition of rosella extract also does not significantly affect the resulting film thickness. The more the concentration of rosella extract is added, the thickness of the resulting film tends to decrease, but not significantly (Dewi et al., 2010).

Leerahawong et al. (2011) explains that the edible film thickness due to differences in the concentration of film-makers, while the volume of film of the solution are poured into each of the same plate. This resulted in the total solids in the film after drying increases and polymers making up the matrix movies more and more. The thickness between the various types of film can cause by the composition formula, of different films.

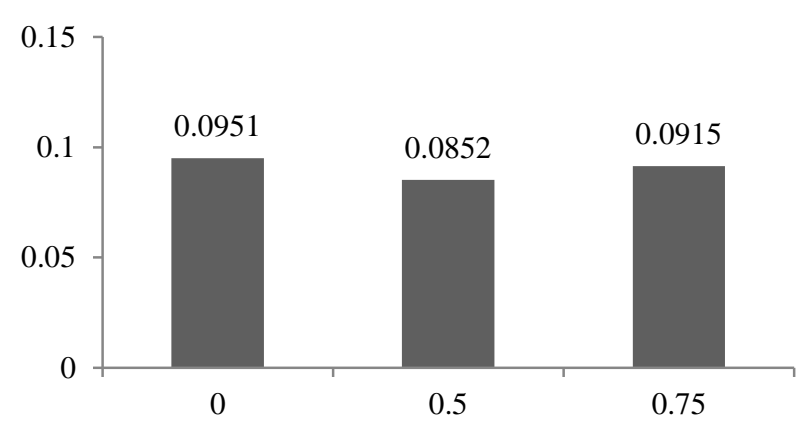

Figure 5. Graph of thickness vs rosella extract variation.

\section{Tensile Strength}

The results of the measurement of tensile strength are presented in Figure 6. It appears that the value of the tensile strength composite edible film surimi-starchglycerol-rosella extract produced ranged from 0.39 to $0.70 \mathrm{~N}$. The addition of 0.5 gram rosella extracts initially lower the value of the tensile strength of the edible film to $0.39 \mathrm{~N}$. The addition of 0.75 grams rosella extract can increase the value of the tensile strength of the edible film becomes $0.52 \mathrm{~N}$, but still relatively lower than edible film without the addition of extract of rosella (Dewi et al., 2010).

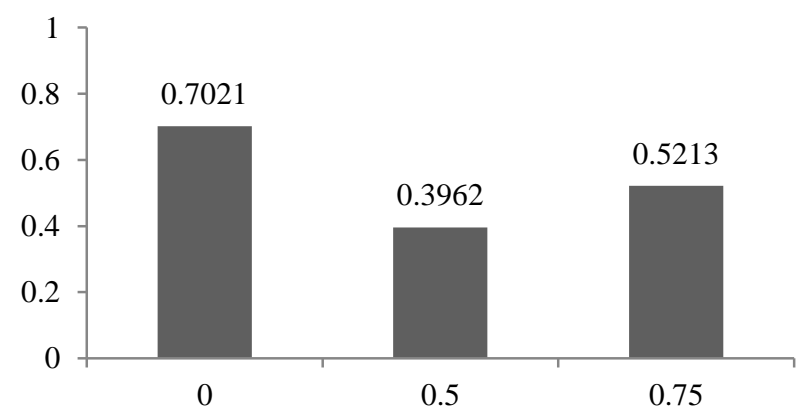

Figure 6. Graph of tensile strength vs rosella extract variation.

The data obtained show that the more rosella extract is added, and then it tends to lower the value of tensile strength of the resulting edible film. The addition of $0.75 \mathrm{~g}$ rosella extract slightly increases tensile strength relative value of the addition of 0.5 grams rosella extract. This is because more film added can increase the density of the resulting film that is not easily torn. Figure 6 also shows that the trend of edible film tensile strength value is almost equal to the thickness of the edible film, so it cannot be used as a standard of determining the quality of the food was good coating.

\section{Elongation}

Elongation measurement results showed in Figure 7. Result shows that the elongation value of the composite 
edible film of surimi-starch-glycerol-rosella extract ranged $21,47-24.95 \%$. Best elongation value contained in the addition of 0.5 grams of rosella extract.

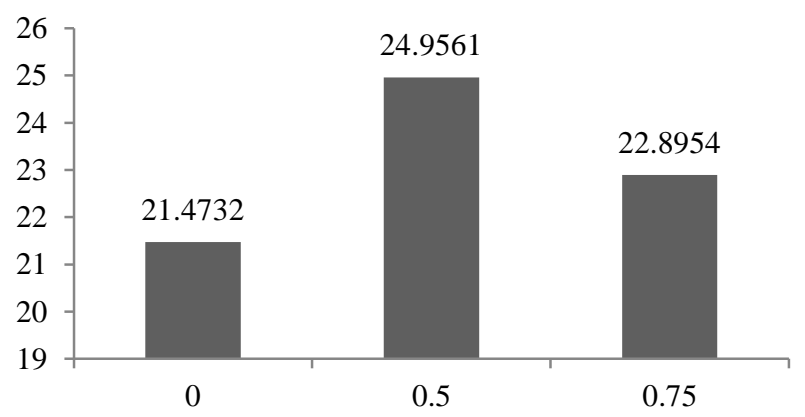

Figure 7. Graph of elongation vs rosella extract variation.

Elongation measurement showed that the addition of rosella extract tends to increase the value of the elongation of edible film. An edible film is said to be used as food coatings if they have a high value percent elongation and water vapor transmission rate is relatively low. This is because of a growing number of its constituent components, the edible film more tightly. Percent elongation produced is inversely proportional to the thickness and tensile strength.

\section{Water Vapor Transmission Rates (WVTR)}

The WVTR measurement of edible film composite are shown in Figure 8.

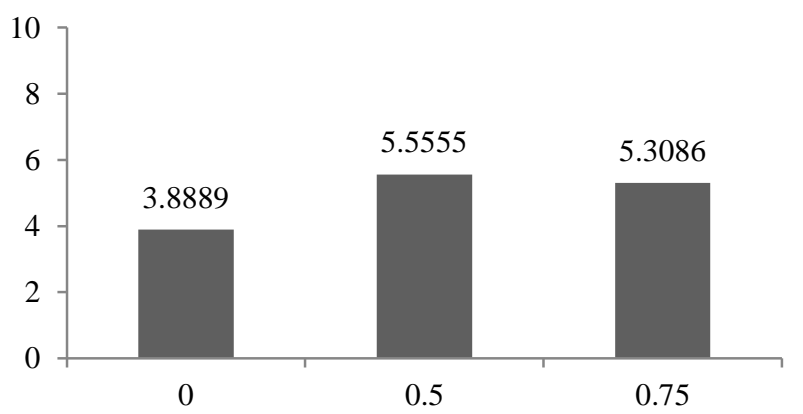

Figure 8. Graph of WVTR vs rosella extract variation.

Based on the Figure 8, it showed that the greater the amount of Rosella added, the greater the WVTR. A better edible film is a film that has a high elongation and low WVTR values.

\section{Charaterization of Fourier Transform Infrared Spectroscopy}

Rosella petals extracts were analyzed using FT-IR spectrophotometer to determine the character of the resulting functional groups. The spectrum is presented in Figure 9. The identification of functional groups on the extract rosella flower petals carried on the wave number $4000-400 \mathrm{~cm}^{-1}$. FT-IR spectrum at rosella flower petals extracts showed some characteristic absorption band in the absorption peaks.

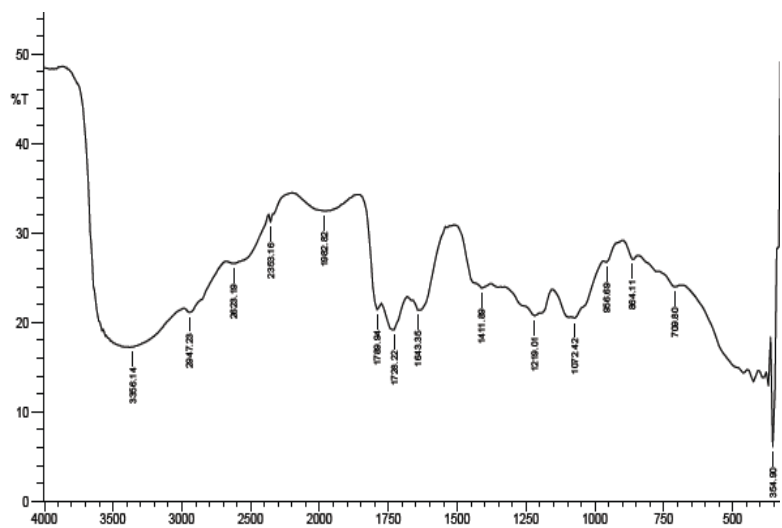

Figure 9. FT-IR spectrum of rosella extract.

Based on the FT-IR spectrum in Figure 9, it appears the wide absorption at wave number $3356.14 \mathrm{~cm}^{-1}$ indicating the $\mathrm{OH}$ absorption band. Wavenumber $2947.23 \mathrm{~cm}^{-1}$ indicating their $\mathrm{C}-\mathrm{H}$ groups are strengthened by their absorption at wavenumber 1411.89 $\mathrm{cm}^{-1}$. Both of these absorptions indicate methyl group in edible film cluster. Absorption around wavenumber $1728.22 \mathrm{~cm}^{-1}$ indicates the group of Carbonyl. While C $=\mathrm{C}$ group indicated by adsorption at wave number $1643.35 \mathrm{~cm}^{-1}$.

Moulana (2012), stated that the absorption at wavenumber $3348.25 \mathrm{~cm}^{-1}$ indicating their alcohol groups are supported by the appearance of absorption at wavenumber $1044.35 \mathrm{~cm}^{-1}$ to $\mathrm{C}-\mathrm{O}$ bond alcohol. Absorption at wavenumber $1706.30 \mathrm{~cm}^{-1}$ indicate the presence of $\mathrm{C}=\mathrm{O}$ carbonyl group. The presence of the $\mathrm{C}=\mathrm{C}$ double bonds of aromatic demonstrated by a sharp absorption at wave number $1634.95 \mathrm{~cm}^{-1}$ which is supported also by the appearance of absorption at wave number $709.80 \mathrm{~cm}-1$ to $\mathrm{C}-\mathrm{H}$ bond. Based on the FT-IR spectra interpretation rosella extract, it can be concluded that the rosella extract containing anthocyanin compounds shown by their group $\mathrm{C}=\mathrm{O}, \mathrm{C}-\mathrm{O}$ and $\mathrm{C}=\mathrm{C}$ which is the structure of anthocyanin.

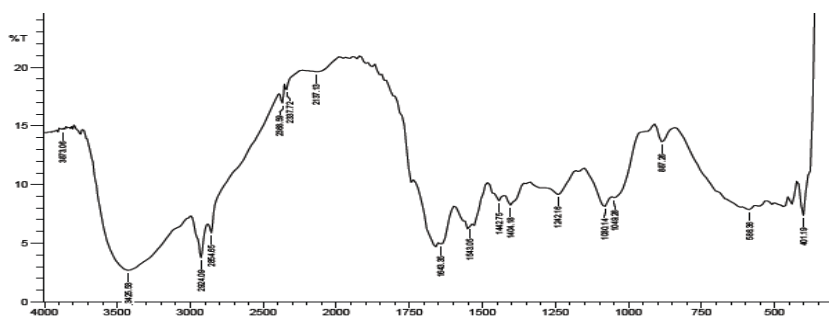

Figure 10. FT-IR spectrum of surimi.

FT-IR spectrum of Surimi is presented in Figure 10. It showed their wide absorption at $3425.58 \mathrm{~cm}^{-1}$ due to 
the strain $\mathrm{NH}$ associated with hydrogen bonds and the $\mathrm{OH}$ group. Uptake of $\mathrm{N}-\mathrm{H}$ is not visible as it is covered by the $\mathrm{OH}$ absorption. Absorption at wavenumber $2924.09 \mathrm{~cm}^{-1}$ indicates the presence of an amine group stretching. A bending amine group showed at wavenumber $2854.65 \mathrm{~cm}^{-1}$ with a sharp peak. This indicates that the amide binds to the $\mathrm{CH}_{2}$ strain. In addition there is absorption at wavenumber $3873.06 \mathrm{~cm}^{-}$ ${ }^{1}$ which indicate the presence of free $\mathrm{NH}$ groups.

Absorption peaks at 1643.35 wave numbers indicate a carbonyl $(\mathrm{C}=\mathrm{O})$. According to Poedjiadi (2009) absorption at wave number $1636-1661 \mathrm{~cm}^{-1}$ showed absorption of amide group. This amide catchment area showed strain $\mathrm{C}=\mathrm{O}$ and $\mathrm{OH}$ groups are paired with a carboxyl group. Next on the wave number $1442.75 \mathrm{~cm}^{-1}$ indicates $\mathrm{CH}_{2}$ bending and deformation $\mathrm{NH}$ bond in the protein. Based on the surimi's FT-IR spectrum interpretation above, it can be concluded that the surimi protein shown their amide groups $(\mathrm{NH})$.

Edible films produced spectra identification of cluster compounds using FTIR spectrophotometer. The resulting spectra are presented in Figure 11.

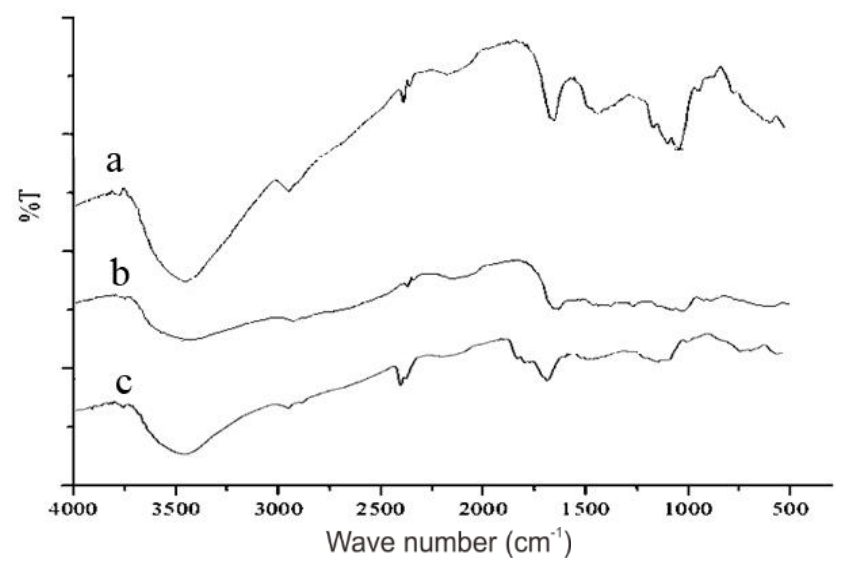

Figure 11. FT-IR spectra of edible film starch-glyserol (a), starchglyserol-surimi (b), and starch-glyserol-surimi- rosella extract (c).

Starch-glycerol spectrum is shown in Figure 11.a, starch-glycerol-surimi in Figure $11 . b$ and starchglycerol-surimi Rosella extract in Figure 11.c. The presence of $\mathrm{OH}$ groups on edible film showed by absorption at wavenumber $3448.72 \mathrm{~cm}^{-1}$. The absorption shifted to $3425.58 \mathrm{~cm}^{-1}$ in the edible film with the addition of surimi. The existence of the $\mathrm{CH}$ (stretching) groups of edible film showed in wavenumber 2931.80. Addition of surimi edible film shown in wave numbers $2924.09 \mathrm{~cm}^{-1}$.

New absorption appears on edible film with the addition of surimi. The uptake appears at wave number $2862.36 \mathrm{~cm}^{-1}$ which indicates the presence of an amine group that binds to the stretching of $\mathrm{CH}_{2}$ groups. New absorption also appears on edible film with the addition of surimi. The uptake appears at wave number 2299.15 $\mathrm{cm}^{-1}$. Group $\mathrm{C}=\mathrm{O}$ (carbonyl) on edible film tapioca and edible film with the addition of surimi shown in wave number $1635.64 \mathrm{~cm}^{-1}$. The shift of wave numbers show that the polymerization reaction time of the blending of the edible film and shows the interaction between polymers occurs.

Figure 11.c of FT-IR surimi edible film-starchglycerol-rosella extract spectra showed some shift wave numbers compared to edible starch-glycerol composite film that is at $2901.60 \mathrm{~cm}^{-1}$ to $2924.09 \mathrm{~cm}^{-1}$ and 1331 $\mathrm{cm}^{-1}$ to $1334.74 \mathrm{~cm}^{-1}$. Some of the absorption band is also changing the intensity and emerging new absorption band. FT-IR spectra showed a broad absorption on say 3400-3500 cm-1 wave. Khopkar (2008), explains that the absorption band at wave number $3600 \mathrm{~cm}^{-1}$ indicate the presence of $\mathrm{OH}$ groups on edible film $\mathrm{OH}$.

The absorption of tapioca with the addition of surimi and Rosella is located at wavenumber $3448.72 \mathrm{~cm}^{-1} . \mathrm{CH}$ (stretching) between edible films edible film tapioca with the addition of surimi and rosella extract is shown in wave number 2924.09 and $2854.65 \mathrm{~cm}^{-1}$. The new spectra appear on edible film with the addition of surimi and rosella extract. The uptake appears at wave number $2862.36 \mathrm{~cm}^{-1}$ which indicates the presence of an amine group that binds to a stretch stretching $\mathrm{CH}_{2}$.

In addition, the new spectra also appear on edible film with the addition of surimi and rosella extract. The uptake appears at wave number $2299.15 \mathrm{~cm}^{-1}$. Group C $=\mathrm{O}$ (carbonyl) on tapioca ediblefilm and edible film with the addition of surimi and rosella extract is shown in wave number $1635.64 \mathrm{~cm}^{-1}$. The shift wave numbers show that the polymerization reaction time of the blending of the edible film and shows the interaction between polymers occurs. FT-IR spectra in Figure 10 shows that the addition of surimi and rosella extract does not change the pattern of uptake significantly edible film.

It is common because the main ingredients of the edible film are tapioca and glycerol so that the pattern of IR absorption of three quite similar edible film. Differences absorption occurs only in some shift in absorption of a wave shift. The emergences of new peaks indicate the presences of a bond between the materials were mixed. Differences in intensity indicate the bond between the materials grows denser and more complex.

\section{CONCLUSION}

The research showed that the addition of surimi and rosella flower extract significantly increase up to $27 \%$ of the elongation of Edible film.

\section{REFERENCES}

Akbar, F., Anita, Z. Harahap, H. 2013. Pengaruh Waktu Simpan Film Plastik Biodegradasi Dari Pati Kulit Singkong Terhadap Sifat Mekanikalnya. Jurnal Teknik Kimia USU. 2 (2). 
Amaliya, R.R., Putri W.D.R. 2014. Karakterisasi Edible Film Dari Pati Jagung Dengan Penambahan Filtrat Kunyit Sebagai Antibakteri. Jurnal Pangan dan Argoindustri. 2 (3).

Awwaly, K.U.A., Manab, A., Wahyuni, E. 2010. Pembuatan Edible Film Protein Whey: Kajian Rasio Protein dan Gliserol Terhadap Sifat Fisik dan Kimia. Jurnal Ilmu dan Teknologi Hasil Ternak. 5 (1): 45-46.

Badan Standarisasi Nasional. Standar Nasional Indonesia. Surimi Beku. SNI 2694. Jakarta: Badan Standarisasi Nasional. 2013.

Bourtoom, T., Chinnan, M.S.; Jantawat, P., Sanguandeekul, R. 2006. Effect of Select parameters on the Properties of Edible Film From Water-Soluble Fish Protein in Surimi WashWater. Departemen of Technology, Faculty of Science. 39: 405-418.

Cahyadi, W. 2009. Analisis dan Aspek Kesehatan Bahan Tambahan Pangan.; Bumi Aksara: Jakarta.

Chinabhark, K., Benjakul, S., Prodpran, T. 2007. Effect of pH on the Properties of Protein-Based Film from Bigeye Snapper (Priacanthus tayenus) Surimi. Bioresource Technology.

Dewi, R.K. 2010. Stabilizer Concentration and Sucrose to the Velva Tomato Fruit Quality. Jurnal Teknik Kimia. 4 (2).

Embuscado, M.E., Huber, K.C. Ed. 2009. Edible Film and Coating For Food Applications. Springer: New York. p 3233.

Garnida, Y. 2007. Memperpanjang Umur Simpan Buah Durian Terolah Minimal dengan Formulasi Bahan Edible Coating Pada Suhu Beku. Jurnal Teknologi Pangan. 2 (9).

Gennadios, A. Ed. 2002. Protein Based Films and Coatings. CRC Press: USA.

Hambali. Hambali, E., S. Mujdalipah, A.H. Tambunan, A.W. Pattiwiri, dan R. Hendroko. 2007. Teknologi Bioenergi. Jakarta: Agromedia.

Hayati, E.K., Budi, U.S., Hermawan, R. 2012. Konsentrasi Total Senyawa Antosianin Ekstrak Kelopak Bunga Rosella (Hibiscus Sabdariffa L): Pengaruh Temperatur dan $\mathrm{pH}$. Jurnal Kimia. 6 (2): 138-147

Isnaini, L. 2010. Ekstraksi Pewarna Merah Cair Alami Berantioksidan dari Kelopak Bunga Rosella (Hibiscus Sabdariffa L) dan Aplikasinya Pada Produk Pangan. Jurnal Teknologi Pertanian. 11 (1): 18-26.

Khopkar, S.M. 2008. Konsep Dasar Kimia Analitik. UI Press: Jakarta.

Krochta. 1994. Edible Coating and Film to Improve Food Quality; CRC Press: New York

Leerahawong, A., Tanaka, M.; Okazaki, E., Osako, K. 2011. Effects of Plasticizer Type and Concentration on the Physicochemical Properties of Edible Film from Squid Todarodes pacificus Mantle Muscle. Food Science and Technology. 77: 1061-1068.

Marwati, S. 2012. Ekstraksi dan Preparasi Zat Warna Alami Sebagai Indikator Titrasi Asam Basa. Prosiding Seminar Nasional Penelitian, pendidikan dan Penerapan MIPA, Fakultas MIPA, Universitas Negeri Yogyakarta.

Moulana, R., Juanda., Rohaya, S., Rosika, R. 2012. Efektivitas Penggunaan Jenis Pelarut dan Asam dalam Proses Ekstraksi Pigmen Antosianin Kelopak Bunga Rosella (Hibiscus
Sabdariffa L). Jurnal teknologi dan Industri Pertanian Indonesia. 4 (3).

Murdianto, W., Marseno, D.W., Haryadi. 2005. Sifat Fisik dan Mekanik Edible Film dari Daun Janggelan (Mesona palustris Bl). Agrosains. 18 (3).

Park, J.W. 2004. Surimi and Surimi Seafood Second Edition; Taylor and Francis Group: New York.

Poedjiadi, A.; Supriyanti, F.M.T. 2009. Dasar-Dasar Biokimia. UI-Press: Jakarta

Robinson, T. 1991. Kandungan Organik Tumbuhan tinggi Edisi Keenam: Terjemahan Prof. Dr. Kokasih Padmawinata.; ITB: Bandung.

Santoso, J., Yasin, A.W.N., Santoso. 2007. Perubahan Sifat Fisiko-Kimia Daging Lumat Ikan Cucut dan Pari Akibat Pengaruh Pengkomposisian dan Penyimpanan Dingin. Jurnal Perikanan dan Kelautan. 1: 1-7.

Santoso, B., Saputra, D., Pambayun, R. 2004. Kajian Teknologi Edible Coating Dari Pati dan Aplikasinya Untuk Pengemas Primer Lempok Durian. Jurnal Teknologi dan Industri Pangan. XV (3).

Santoso, B., Pratama, F., Hamzah, B., Pambayun, R. 2011 Pengembangan Edible Film Dengan Menggunakan Pti Ganyong Termodifikasi Ikatan Silang. Jurnal Teknologi dan Industri Pangan. XXII (2).

Santoso, B., Herpandi, A., Pambayun, R. 2013. Karakteristik Film Pelapis Pangan Dari Surimi Belut Sawah dan Tapioka. Jurnal Teknologi dan Industri Pangan. 24 (1).

Setiono, M., Dewi, A. 2013. Penentuan Jenis Solven dan pH Optimum Pada Analisis Senyawa Delphinidin Dalam Kelopak Bunga Rosela Dengan Metode Spektrofotometri UV-VIS. Jurnal Teknologi Kimia dan Industri. 2 (2): 91-96.

Sinaga, L.L., Rejekina, M.S.S., Sinaga, M.S. 2013. Karakteristik Edible Film Dari Ekstrak Kacang Kedelai Dengan Penambahan Tepung Tapioka dan Gliserol Sebagai Bahan Pengemas Makanan. Jurnal Teknik Usu, 2 (4).

Skurtys, O., Acevedo, C., Pedreschi, F., Enrione, J., Aquilera, J.M. 2009. Food Hydrocolloid Edible Films and Coatings. Departement of Food Science and Technology. Universidad de Santiago de Chile.

Supriyanti, F. M., Dwiyanti, G., Muliani, P.D. 2013. Surimi dari Ikan Beloso (Saurida tumbil Sp) dan Analisis Kandungan Gizinya. Jurnal Sains dan Teknologi Kimia. 4 (2).

Suzery, M.; Lestari, S.; Cahyono, B. 2010. Penentuan Total Antosianin dari Kelopak Bunga rosella (Hibiscus Sabdariffa L) Dengan Metode Maserasi dan Sokshletasi. Jurnal Sains \& Matematika (JSM). 18 (1).

Valenzuela, C., Abugoch, L., Tapia, C. 2013. Quinoa ProteinChitosan-Sunflower Oil Edible Film: Mechanical, Barrier and Structural Properties. Food Science and Technology. 50: 531537.

Warsiki, E., Putri, C. D. W. 2012. Pembuatan Label/Film Indikator Warna dengan Pewarna Alami dan Sintesis. EJurnal Agroindustri Indonesia. 1 (2): 82-87. 